\title{
A comparative evaluation of bioagents and chemicals for the control of stalk rot of Sorghum caused by Dickeya dadantii
}

\section{Prachi Singh*}

Department of Plant Pathology, College of Agriculture, G. B. Pant University of Agriculture and Technology, Pantnagar-263145, U.S. Nagar (Uttarakhand), India Yogendra Singh

Department of Plant Pathology, College of Agriculture, G. B. Pant University of Agriculture and Technology, Pantnagar-263145, U.S. Nagar (Uttarakhand), India

Jyotika Purohit

Department of Plant Pathology, College of Agriculture, G. B. Pant University of Agriculture and Technology, Pantnagar-263145, U.S. Nagar (Uttarakhand), India

Anupam Maharshi

Department of Mycology and Plant Pathology, Institute of Agricultural Sciences, Banaras Hindu University, Varanasi - 221005 (U.P.), India

*Corresponding author. E-mail: singhprachibhu16 @gmail.com

\begin{abstract}
Stalk rot sorghum caused by Dickeya dadantii (syn. Erwinia chrysanthemi) is a devastating sorghum disease and is highly detrimental to sorghum cultivation in tarai region of India. The bacterium disrupts and disintegrates vascular bundles of sorghum stem manifesting slimy soft rot symptom. In vitro studies on bioagents and chemicals revealed that among bioagents assessed Pseudomonas fluorescens strain Psf-173 and Trichoderma harzianum strain Th-14 surpassed the other biological control agents whereas among chemicals, oxytetracycline and tetracycline were outstanding than other chemicals and their combination products used for the control of stalk rot of Sorghum caused by $D$. dadantii. Field trial with pre-plant soil application had maximum reduction in disease severity in treatment with antibiotic oxytetracycline $(28.18 \%)$ whereas trial with pre-plant soil application with one $(34.49 \%)$ and two foliar spray $(37.03 \%)$ showed maximum reduction in disease severity in treatment with $P$. fluorescens strain Psf-173. All the three field trials involving pre-plant soil application, pre-plant soil application and one foliar spray and trial with pre-plant soil application and two foliar spray revealed that biological control agent $P$. fluorescens strain Psf-173 alleviates symptom of stalk rot of sorghum and stimulates seed germination and plant growth.
\end{abstract}

Keywords: Dickeya dadantii, oxytetracycline, Pseudomonas fluorescens, Stalk rot, Sorghum

\section{INTRODUCTION}

Sorghum stalk rot is a destructive sorghum disease caused by Dickeya dadantii (syn. Erwinia chrysanthemi). Stalk and top rot of sorghum caused by Erwinia in 1987-88, at Pantnagar, Uttarakhand, destroyed $60-80 \%$ plants of distinct sorghum genotypes (Saxena et al. 1991). The infected stem pith disintegrates with slimy soft-rot symptom and emits foul-smell, eventually leading to wilting of whole plant (Zummo, 1969; Hepperly and Ramos-Davila, 1987; Hseu et al., 2008). The entire length of the stalk or few internodes may rot followed by drying and maceration of internal tissues. Leaves and leaf sheath covering the rotting tissues turn chlorotic with pale-straw colour. Hepperly and Davila (1987) evaluated twenty-two antibiotics against $E$ chrysanthemi pv. zeae under in

\section{Article Info}

DOI:10.31018/jans.v10i3.1862 Received: August 10, 2018

Revised: August 23, 2018

Accepted: August 25, 2018

\section{How to Cite}

Singh, P. et al. (2018). A comparative evaluation of bioagents and chemicals for the control of stalk rot of Sorghum caused by Dickeya dadantii. Journal of Applied and Natural Science, 10(3): $1053-1058$ vitro and in vivo conditions and reported bacterium to be sensitive to tetracycline, chloramphanicol, kanamycin and gentamycin and insensitive to penicillin group of antibiotics. Bleaching powder of $1000 \mathrm{ppm}$ concentration was reported to suppress growth of Ecarotovora ssp. carotovora both in vitro and in vivo application by soil drenching as well enhanced tuber germination (Saini and Parashar, 1981). Chemicals such as streptomycin, streptocycline, terramycin, agrimycin-100, Blitox-50, Dithane M-45, Dithane Z-78, bleaching powder, captan and ziram has been reported to have inhibitory effect on Erwinia (Rangarajan and Chakravarti, 1969; Sinha and Prasad, 1977; Thind and Payak, 1985; Kumar et al., 2016). Biological control agents as Bacillus subtilis, $P$. fluorescens, actinomycetes and VAM fungi has been studied to provide significant control of $E$ chrysanthemi 
(Karkouri et al., 2010 and Nagaraj et al., 2012 ).

The aim of the present work was to study- i) In vitro assessment of antagonistic potential of biocontrol agents and chemicals against $D$. dadantii. ii). Field trail to assess the efficacy of biocontrol agents and chemicals tested in vitro against the bacterium.

\section{MATERIALS AND METHODS}

In vitro assessment of antagonistic potential Biocontrol agents by Dual culture assay: Biological control agents as isolates of Trichoderma, Th-14, UKT-22 and UKT-40 and P. fluorescens isolate, Psf-173 were procured from Biological control laboratory, Pantnagar, and were examined against $D$ dadantii for their antagonistic potential by dual culture technique (Morton and Stroube, 1955). Under aseptic conditions, nutrient agar medium (NAM) was poured in a sterilized petri plates and left to solidify. The cell suspension of conc. $10^{4}$ cell $/ \mathrm{ml}$ was prepared from $24 \mathrm{~h}$ old culture of test bacterium and five $\mathrm{mm}$ disk dipped in bacterial suspension and 4 days old culture of biocontrol agents was cut into disk with sterilized cork borer, and were placed on solidified NAM in a manner that they lied just opposite to each other along the diameter of the petri plate. The discs were placed at distance of $2 \mathrm{~cm}$ from the periphery of petri plates in a straight line followed by incubation at $28 \pm 1^{\circ} \mathrm{C}$. The disk dipped in bacterial suspension, inoculated centrally on NAM amended Petri plate served as control. The experiment was performed in completely randomized design (CDR) with three replications. Percent inhibition of the test pathogen was calculated 3-5 days after incubation at $28^{\circ} \mathrm{C}$ by comparing the growth of the test pathogen (after parasitization) with the control. Inhibition zone was calculated on the basis of formula, per cent inhibition $(\mathrm{PI})=\mathrm{C}-\mathrm{T} / \mathrm{C} \times 100$ Where, $\mathrm{PI}=$ per cent inhibition, $\mathrm{C}=$ Radial growth (cm) of test pathogen in absence of antagonist (cm), T = Radial growth $(\mathrm{cm})$ of test pathogen in presence of antagonist (Skidmore and Dickinson, 1976).

Chemicals by disc diffusion method: Antibiotic susceptibility test was performed by Kirby-Bauer and Stroke's method. The paper discs of $5 \mathrm{~mm}$ diameter were prepared from whatman filter paper no. 1 were placed in glass vial and sterilized in autoclave at $121^{\circ} \mathrm{C}$ for 15 minutes. Nutrient agar plate was seeded with $100 \mu \mathrm{l}$ of the test bacterium under aseptic condition. The discs dipped in different antibiotics concentrations 100, 200, 400, 500 and $1000 \mathrm{ppm}$ were placed under aseptic condition on the seeded nutrient agar plate. Each petri plate should have only 4 discs, 3 of different concentration and one of control (dipped in sterile water), placed precisely ensuring contact of disc with medium. Plates are examined for zone of inhibition after incubation at $28^{\circ} \mathrm{C}$ for 48 hours (2-3 days). The inhibition zone diameter was measured including disc diameter (as judged by the unaided eye). Calculation of percent inhibition was done on basis of formula: Percentage of inhibition $=R_{1}-R_{2} / R_{1} \times 100$. Where, $R 1=$ Radius of the radial growth of the pathogen towards opposite side in control plate, $\mathrm{R} 2=$ Radius of the radial growth of the pathogen towards the opponent antagonist in test plate (Hedges, 1999).

Field Assessment: The field experiment was designed and conducted at Livestock Research centre, amid 2014 Kharif season at G.B. Pant University of Agriculture and Technology, Pantnagar to compare the potentiality of bioagents and chemicals screened by in vitro assay against $D$ dadantii. Experiment was performed in Randomized Block Design (RBD) with 3 replications of each treatment. The sorghum seedlings of variety SPV 2128 was artificially inoculated with bacterial suspension of $D$ dadantii, Pantnagar isolate containing $0.7 \%$ of Tween- $80(\mathrm{v} / \mathrm{v})+1 \times 10^{7}$ cells $/ \mathrm{ml}$ (cfu) by leaf whorl inoculation method. The sterilized water was used to inoculate control plants. The treatments for evaluation of bioagents and chemicals for field experiment were designed as follows:-

a) Pre- plant soil application

b) Pre-plant soil application + one foliar spray

c) Pre-plant soil application + two foliar spray

Disease severity was recorded 40 and 60 days after sowing (DAS). The observations on growth parameters, seed germination (\%), plant height (cm) andstem diameter $(\mathrm{cm})$ was first recorded 20 DAS from all the plots and then again at 40 DAS from each plot separately by taking random samples. Statistical analysis of data was carried using SPSS software.

\section{RESULTS AND DISCUSSION}

\section{In vitro results}

Screening of biocontrol agent: The antagonistic potential of biological control agents was assessed against the pathogen by dual culture assay. The $P$. fluorescens strain Psf-173 was par excellence among bioagents with maximum $(71.75 \%)$ reduction of radial growth (Table 1$)$. The competent biocontrol agent, recorded under in vitro conditions were further evaluated for competence under field conditions.

$\mathrm{Xu}$ and Gross (1986) found that Fluorescent Pseudomonads showed high level of antagonistic activity against $E$. carotovora. The $P$. fluorescens has been reported by various researchers to restrict the growth of disease causing microorgan-

Table 1. Dual culture assay for efficacy of biocontrol agents against $D$ dadantii.

\begin{tabular}{lll}
\hline Treatment & $\begin{array}{l}\text { Colony diame- } \\
\text { ter }(\mathbf{c m})\end{array}$ & $\begin{array}{l}\text { Reduction in col- } \\
\text { ony diameter (\%) }\end{array}$ \\
\hline Th -14 & 1.26 & 68.50 \\
UKT -22 & 2.16 & 46.00 \\
UKT -40 & 2.30 & 42.50 \\
Psf -173 & 1.13 & 71.75 \\
C(Control) & 4.00 & 0.00 \\
CD at 5\% & 0.22 & \\
sem & 5.97 & \\
\hline
\end{tabular}


Singh, P. et al. / J. Appl. \& Nat. Sci. 10 (3): 1053 -1058 (2018)

Table 2. Disk diffusion assay to determine efficacy of chemicals in vitro.

\begin{tabular}{|c|c|c|}
\hline Treatment & $\begin{array}{l}\text { Concentra- } \\
\text { tion (ppm) }\end{array}$ & $\begin{array}{l}\text { Zone of inhibition } \\
\text { (Diameter in } \mathrm{cm} \text { ) }\end{array}$ \\
\hline \multirow[t]{5}{*}{ Oxytetracycline } & 100 & 0.83 \\
\hline & 200 & 1.16 \\
\hline & 400 & 1.30 \\
\hline & 500 & 1.86 \\
\hline & 1000 & 3.50 \\
\hline \multirow[t]{5}{*}{ Tetracycline } & 100 & 0.73 \\
\hline & 200 & 0.90 \\
\hline & 400 & 1.10 \\
\hline & 500 & 1.20 \\
\hline & 1000 & 3.10 \\
\hline \multirow[t]{5}{*}{ Blitox - 50} & 100 & 0.00 \\
\hline & 200 & 0.00 \\
\hline & 400 & 0.43 \\
\hline & 500 & 0.70 \\
\hline & 1000 & 2.52 \\
\hline \multirow[t]{5}{*}{ Streptocycline } & 100 & 0.00 \\
\hline & 200 & 0.00 \\
\hline & 400 & 0.95 \\
\hline & 500 & 1.01 \\
\hline & 1000 & 2.06 \\
\hline \multirow{5}{*}{$\begin{array}{l}\text { Bleaching pow- } \\
\text { der }\end{array}$} & 100 & 0.00 \\
\hline & 200 & 0.00 \\
\hline & 400 & 0.00 \\
\hline & 500 & 0.00 \\
\hline & 1000 & 0.86 \\
\hline \multirow{5}{*}{$\begin{array}{l}\text { Streptocycline } \\
+ \text { Blitox }-50\end{array}$} & 100 & 0.00 \\
\hline & 200 & 0.00 \\
\hline & 400 & 0.66 \\
\hline & 500 & 0.73 \\
\hline & 1000 & 1.16 \\
\hline \multirow{5}{*}{$\begin{array}{l}\text { Oxytetracycline } \\
+ \text { Blitox }-50\end{array}$} & 100 & 0.00 \\
\hline & 200 & 0.71 \\
\hline & 400 & 1.06 \\
\hline & 500 & 1.10 \\
\hline & 1000 & 1.60 \\
\hline $\begin{array}{lr}C D \text { at } & 5 \% \\
\text { Treatment } \\
0.68\end{array}$ & & \\
\hline $\begin{array}{l}\text { Treatment } \\
0.57 \\
a^{*} b \\
0.15\end{array}$ & & \\
\hline
\end{tabular}

isms in vitro (Thomashow and Weller, 1988; Hebbar et al., 1992; Rosales et al., 1995).

Screening of chemicals: The in vitro analysis involving fungicide, antibiotics, bleaching powder and combination product of both against $D$ dadantii by disk diffusion method (Table 2), treatment with only antibiotics exhibited better inhibition of $D$ dadantii than the fungicide, bleaching powder or the combination product of both fungicide and antibiotics. Antibiotics exhibited inhibition even at 100, 200 ppm but the fungicides and combination product of fungicide, bleaching powder and antibiotics manifested least inhibition at 100 or 200 concentration ppm. Maximum zone of inhi-

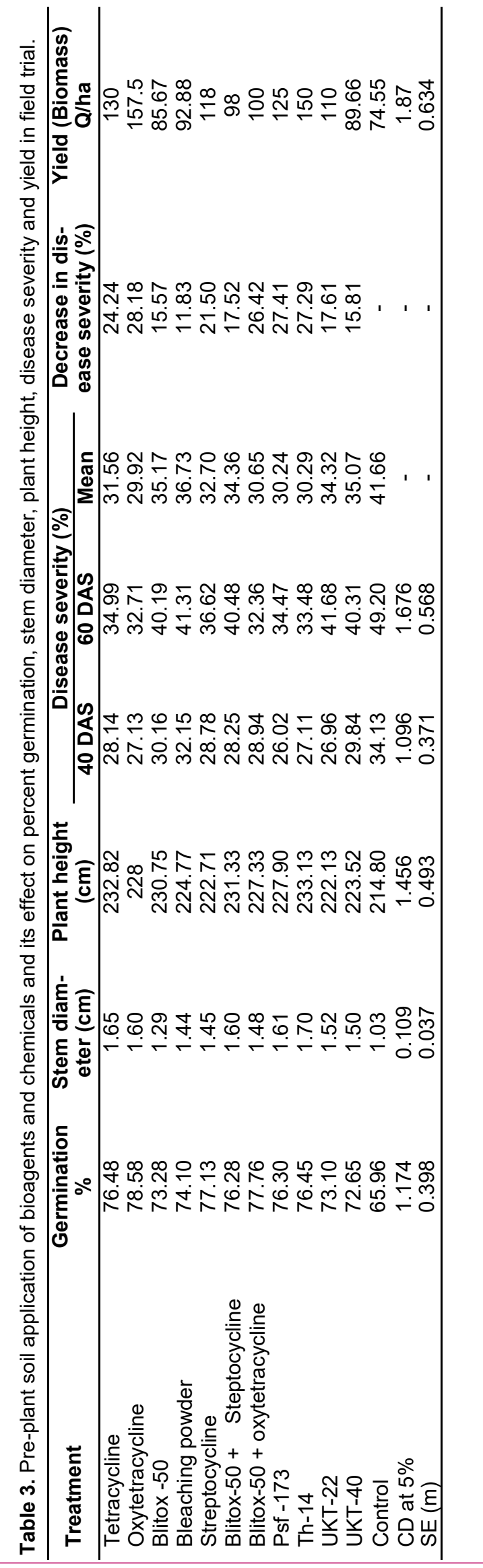


Singh, P. et al. / J. Appl. \& Nat. Sci. 10 (3): 1053 -1058 (2018)
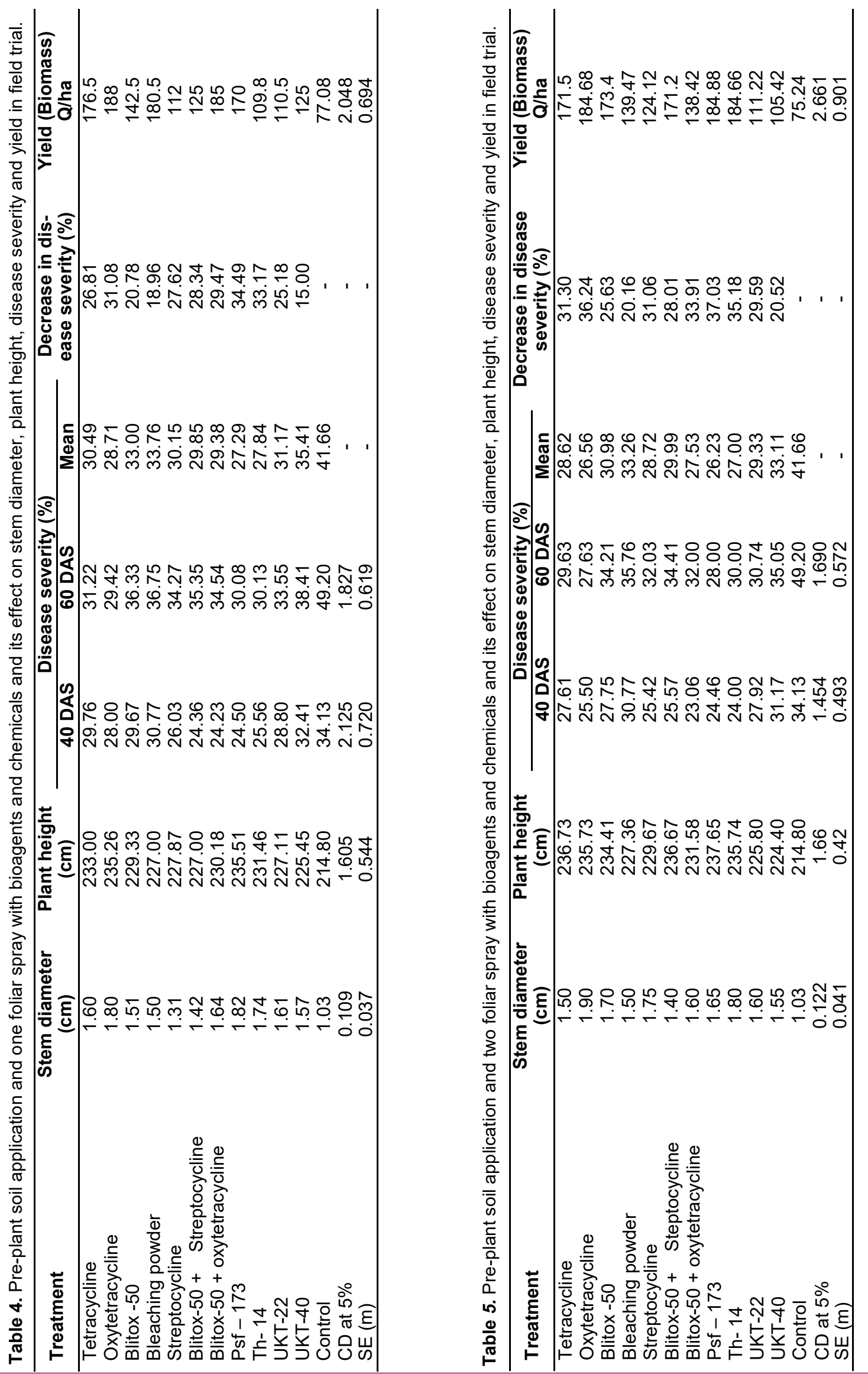
bition was observed with oxytetracycline $(3.50 \mathrm{~cm})$ among all the chemicals used.

Christensen and Wilcoxan (1966) reported control of soft rot erwinia by chemical treatment of seed, soil or foliage of corn. Antibiotics such as streptocycline, streptomycin and terramycin has been reported to be effective against $E$ chrysanthemi even at lower concentration (Chakravarti and Rangarajan, 1966; Rangarajan and Chakravarti, 1969). Saini and Parashar (1981) recorded inhibitory effect of bleaching powder at 1000 ppm concentration against $E$. carotovora ssp. carotovora. $E$. carotovora ssp. carotovora has been reported to be sensitive to streptocycline in banana and potato (Mahmood et al., 1981; Parashar and Sindhan, 1988). Antibiotics streptomycin/ tetracycline 100 ppm mixed with 20 ppm copper fungicides may be used for seed treatment to control soft rot of vegetables by $E$. carotovora pv. carotovora, pv. atroseptica (Verma, 2012).

In vivo results: The result of treatment with only pre-plant soil application is presented in Table 3, clearly demonstrating that disease severity was reduced in all the treatments significantly over control. Maximum seed germination, stem diameter and plant height was observed in treatment with oxytetracycline $(78.58 \%)$, Th-14 $(1.70 \mathrm{~cm})$, Th $-14(233.13 \mathrm{~cm})$ respectively. Whereas maximum reduction in disease severity was observed with oxytetracycline $(28.18 \%)$ followed by those in treatment with Psf-173 and maximum yield was observed for treatment with oxytetracycline (157.5 $\mathrm{Q} / \mathrm{ha}$ ). It is evident from result of treatment with pre-plant soil application and one foliar spray, presented in the Table 4, that disease severity was significantly reduced in all the treatments over control. The treatment with Psf-173 showed maximum reduction in disease severity of $34.49 \%$ followed by Th-14 and oxytetracycline, thickest stem diameter was observed in treatment with Psf-173 $(1.82 \mathrm{~cm})$, plant height was found to be maximum in treatment with Psf-173 $(235.51 \mathrm{~cm})$ and maximum yield was obtained from plot treated with oxytetracycline (188 Q/ha). The result of treatment with pre-plant soil application and two foliar spray are presented in Table 5 indicating that maximum increase in stem diameter was with oxytetracycline $(1.90 \mathrm{~cm})$, maximum increase in plant height was recorded with Psf-173 $(237.65 \mathrm{~cm})$, disease severity was reduced maximum by Psf-173 $(37.03 \%)$ followed by oxytetracycline and Th-14 and maximum yield was obtained in plot treated with Psf-173 (184.88 Q/ha). In field experiment, $P$. fluorescens strain Psf-173 was at par with antibiotic oxytetracycline as far as reduction in disease severity was concerned.

Several other workers as Cronin et al. (1997) while working with soft rot of potato obtained similar result and reported that $P$. fluorescens F113 has ability to produce DAPG, which plays a crucial role in inhibition of $E$. carotovora ssp. atroseptica. Nagaraj et al. (2012) reported use of Bacillus subtilis and $P$. fluorescens for management of $E$. ca- rotovora subsp. carotovora and E. chrysanthemi causing tipover disease of banana. The strains of $P$. fluorescens and $P$. putida has been reported to inhibit soft rot causing bacteria, E. carotovora pv. carotovora and enhances plant growth and yield. The Pseudomonas strains were also found compatible with fungicides used against potato soft rot (Burr et al., 1978). Hajhamed et al. (2007) found that the disease severity of soft rot of potato caused by $E$. carotovora ssp. carotovora was reduced significantly by all tested bioagents (upto $83.5 \%$ ). The biological control agent, $P$. fluorescens has been reported by above workers to inhibit erwinia and enhance crop growth and yield in similar manner to present work. Christiano et al. (2010) found that the foliar spray of oxytetracycline under varying temperature, sunlight and stimulated rainfall condition on peach was effective in controlling Xanthomonas arboricola pv. pruni on stone fruits and $E$. amylovora on pome fruits. Trunk-injection of apple with oxytetracycline reduces incidence of fire blight of apple upto $60 \%$, which was exceptionally higher than those provided by kasugamycin and copper chelates (Aćimović et al., 2014). Efficacy of different antibiotics as oxytetracycline and kasugamycin have been reported in various crops to control erwinia similar to present work in which oxytetracycline was reported to reduce disease severity to considerable extent.

\section{Conclusion}

From both in vitro and in vivo study performed on bioagents and chemicals to control $D$ dadantii it can be concluded that among bioagents used, Psf -173 and Th-14 was par excellence with other biological control agents used. Whereas among chemicals, oxytetracycline and tetracycline were found effective in reducing disease severity and were far much better than the fungicide and bleaching powder used alone and there combination product with antibiotics. It was revealed that from all the three field trials, biological control agent Psf-173 was at par with oxytetracycline as far as reduction in disease severity was concerned. So we can emphasize upon safer use of biological control agents as pseudomonas rather than chemicals or antibiotics as oxytetracycline for management of stalk rot of sorghum. Biological control agent as pseudomonas alleviated stalk rot of sorghum as well augmented plant growth of sorghum. Use of biological control agents protects environment by avoiding superfluous accumulation of chemicals, preventing residue accretion and pollution.

\section{REFERENCES}

1. Aćimović S. G., McGhee G. C., Sundin G.W., Wise J. C. (2014). Evaluation of trunk-injected bactericides and prohexadione-calcium for environmentally friendly control of fire blight (Erwinia amylovora) in apples. In Proceedings of the VII Congress on Plant Protection: Integrated Plant Protection - a KnowledgeBased Step towards Sustainable Agriculture, Forestry 
and Landscape Architecture.

2. Burr, T., Schroth, M.N. and Suslow, T. (1978). Increased potato yields by treatment of seed pieces with specific strains of Pseudomonas fluorescens and P. putida. Phytopathology, 68: 1377-1383.

3. Chakravarti, B.P. and Rangarajan, M. (1966). Streptocycline, an effective antibiotic against bacterial Plant pathogens. Hindustan Antibiotic Bulletin. 8: 209-211.

4. Christensen J.J. and Wilcoxson R.D. (1966). Stalk rot of corn. Monograph No.3. American Phytopathological Society, p 59

5. Christiano R.S.C., Reilly C.C., Miller W.P. and Scherm H. (2010). Oxytetracyclin dynamics on peach leaves in relation to temperature, sunlight, and simulated rain. Plant Disease, 94: 1213-1218.

6. Cronin, D., Moeenne-Loccoz, Y., Fenton, A., Dunne, C., Dowling, D.N. and Fergal O'Gara. (1997). Ecological interaction of a biocontrol Pseudomonas fluorescens strain producing 2,4-diacetylphloroglucinol with the soft rot potato pathogen Erwinia carotovora subsp. atroseptica. FEMS Microbiology Ecology, 23: 95-106.

7. Hajhamed, A.A., Wafaa, M., Abd El-Sayed, A., Abou El-Yazied and Abd El-Ghaffar, N.Y. (2007). Suppression of bacterial soft rot disease of potato. Egypt. Journal of Phytopathology, 35 (2): 69-80

8. Hebbar, K.P., Davey, A.G., Merrin, J., McLoughlin, T.J. and Dart, P.J. (1992). Pseudomonas cepacia, a potential suppressor of maize soil-borne diseasesSeed inoculation and maize root colonization. Soil Biology and Biochemistry, 24 (10): 999-1007.

9. Hedges, A.J. (1999). The influence of factors affecting the critical population density of inoculation on the determination of bacterial susceptibility to antibiotics by disc diffusion methods. Journal of Antimicrobial Chemotherapy. 43: 313.

10. Hepperly and Ramos-Davila. (1987). Erwinia chrysanthemi Burk., McFaddan Dimock: a bacterial whorl and stalk rot pathogen of sorghum (Sorghum bicolour [L.] Moench). Journal of Agriculture of the University of Puerto Rico. 71 (3): 265-275.

11. Hseu, S.H., Kuo, K.C., Lin, H.F. and Lin, C.Y. (2008). Bacterial stalk rot of sorghum occurred in Kimmen area caused by Erwinia chrysanthemi. Plant Pathology Bulletin 17: 257-262.

12.Karkouri, A.E., Hassani, F.Z. E., Mzibri, M.E., BenIemlih, M.E. and Hassouni, M. (2010). Isolation and Identification of an Actinomycete Strain with a Biocontrol Effect on the phytopathogenic Erwinia chrysanthemi 3937VIII Responsible for Soft Rot Disease. Annals of Microbiology. 60(2): 263-68.

13.Kumar, A., Hunjan, M.S., Kaur, H., Singh, P.P. and Kaur, R. (2016). Evaluation of management of bacterial stalk rot of maize (Dickeya zeae) using bioagents and chemical agents. Journal of Applied \& Natural Science. 8(3): 1146-51.

14.Mahmood, S.A.Z.; Ishac, Y.Z.; Abdel-llafez, A.M.;
Farag, N.S. and Fawzi, F.G. (1981). Sensitivity of soft rot bacteria to antibiotics and the role of ampicillinresistant mutants in rot development. Research Bulletin Faculty of Agriculture, Ain shams University, No.1595, $16 \mathrm{pp}$.

15.Morton, D.J. and Stroube, W.H. (1955). Antagonistic and stimulating effects of soil microorganism of Sclerotium. Phytopathology, 45: 417-420.

16.Nagaraj, M.S., Umashankar, N., Palanna, K.B. and Khan, A.N.A. (2012). Etiology and management of tip-over disease of banana by using biological agents. International Journal of Advanced Biological Research. 2(3): 483-86.

17.Parashar, R. D. and Sindhan, G. S. (1988) Efficacy of klorocin and other chemicals in controlling soft rot of potato in field and storage. Indian Journal of Mycology and Plant Pathology. 18:39-42.

18.Rangarajan, M. and Chakravarti, B.P. (1969). Efficacy of antibiotics and fungicides against corn stalk rot bacteria. Hindustan Antibiotic Bulletin. 11(3):177.

19.Rosales, A.A., Thomashow, L., Cook, R.J. and Mew, T.W. (1995). Isolation and identification of antifungal metabolites produced by rice-associated antagonistic Pseudomonas spp. Phytopathology, 85: 1028-1032.

20.Saini, L.C. and Parashar, R.D. (1981) Efficacy of stable bleaching powder in controlling soft rot and black leg of potato. Indian Phytopathology, 33:409414

21.Saxena, S.C., Mughogho, L.K. and Pande, S. (1991). Stalk rot and top rot of sorghum caused by Erwinia chrysanthemi. Indian Journal of Microbiology, 31 (4): 435-441.

22.Skidmore, A. M., \& Dickinson, C. H. (1976). Colony interactions and hyphal interference between Septoria nodorum and phylloplane fungi. Transactions of the British Mycological Society, 66(1):57-64.

23.Sinha, S. K., and Prasad, M. (1977). Studies on certain aspects of chemical control of bacterial stalk rot disease of maize. Zentralblatt für Bakteriologie, Parasitenkunde, Infektionskrankheiten und Hygiene. Zweite Naturwissenschaftliche Abteilung: Allgemeine, Landwirtschaftliche und Technische Mikrobiologie, 132(1), 89-92.

24.Thind, B.S. and Payak, M.M. (1985). A review of bacterial stalk rot of maize in India. Tropical Pest Management, 31 (4): 311-316.

25.Thomashow, L.S. and Weller, D.M. (1988). Role of a phenazine antibiotic from Pseudomonas fluorescens in biological control of Gaeumannomyces graminis var. tritici. Journal of Bacteriology, 170: 3499-3508.

26.Verma, J.P. (2012). The Bacteria. $4^{\text {th }}$ edition. Malhotra Publishing House, New Delhi. p227.

27.Xu, G.W. and Gross, D.C. (1986). Field evaluations of the interactions among fluorescent Pseudomonads, Erwinia carotovora, and yields. Phytopathology, 76: $423-430$

28.Zummo, N. (1969). Bacterial soft rot, a new disease of sweet sorghum. Phytopathology, 59:119. 